\title{
IN MEMORIAM: WILLIAM GERSON ROLIM DE CAMARGO (1920 - 1987)
}

O Professor William Gerson Rolín de Canargo nasceu e realizou toda a sua carreira academíca na cidade de São Paulo. Após os cursos regulares concluídos no Líceu Río Branco de Såo Paulo, obteve os títulos de Bacharéu e de Licenciado en História Natural pela antiga Faculdade de Filosofia Ciências e Letras da Universidade de Săo Paulo (FFCL-USP), e o de engenheiro pela Faculdade de Engenharia da Universidade Mackenzie de Sðo Paulo. Ingressou no Departamento de Mineralogia e Petrografia da FFCL-USP no ano de 1940 e quatro anos depois defendeu tese de dou toramento na qual estudou a gênese de una jazida de molibdenita do Rio Grande do Sul. Realizou cursos de extensão na Universidade de Harvard nos Estados Unidos da América no período 1946-1947 onde teve a oportunidade de trabalhar com os Profs. Larsen, Gibson, Hurlbut, Palache e Frondel, entre outros grandes nomes da época. Prosseguindo sua carreira acadênica obteve o título de Livre-docente en 1957 após defender tese sobre a mineralogia da jazida de ouro da Mi na de Morro Velho, Minas Gerals. Segulu-se, então, um período de grande produtividade em sua carreira, coincidindo com o infcio das atividades do Curso de Geologia de Săo Paulo. Efetuou diversas viagens ao exterior visitando laboratórios de pesquisa e participando de diversos con gressos internacionais de cristalografia e de mineralogia. No plano adninistrativo, implantou - laboratórío de luz refletida e expandiu o laboratório de Raios $x$, adquírindo cámaras de pó e de monocristal. Tendo en vista a falta de textos didáticos nos primeiros anos de funcionamen to do Curso de Geologia, elaborou apostilas de excelente conteúdo didático versando sobre criśs talografia geonétrica e óptica cristalina, áreas que constituiram sempre o seu principal inte resse cientifico. Esses textos esgotaram-se rapidamente e já eståo a merecer un trabalho de reediçẫo. Conheceu o climax de sua carreira acadêmica en 1966 ao tornar-se Catedrátíco de Mine ralogia, aliás, um dos últimos da USP pois o cargo foi extinto no final da década. Em sua tese de cátedra estudou meticulosamente os minerais uraniferos encontrados com certa frequêencia nos pegnatitos da regiđo de Perus, Săo Paulo. Além da diversificada metodologia utilizada para a época, Introduzíu variantes em diversos métodos analíticos, o que estava ben de acordo com o seu temperamento sempre voltado para os aspectos matemáticos dos problenas. Un dos seus últimos trabalhos fol a tradução e adaptação do livro de C.Bunn "Cristals: seu papel na natureza e na ciência" que ele executou con cuidado esmerado produzindo un texto preciso, rico en inforna çōes cristalográficas e nineralógicas, e de leitura extremamente agradável. O Professor wil1 lan Gerson Rolim de Canargo deixa una abra vasta que inclui mais de una centena de trabalhos entre teses, apostilas didáticas, resunos de congressos, artigos clentificos e de divulga çăo cientifica.

Sฮ̄o Paulo, maio de 1988.

Prof. Dr. Darcy Pedro Svisero

INSTITUTO DE GEOCIENCIAS - USP 